Article

\title{
Can Music “Mirror" God? A Theological-Hermeneutical Exploration of Music in the Light of Arvo Pärt's Spiegel im Spiegel
}

\author{
Maeve Louise Heaney
}

St. Pauls Theological College, Australian Catholic University, 1100 Nudgee Road, Banyo, Queensland 4014, Australia; E-Mail: Maeve.Heaney@acu.edu.au; Tel.: +61-7-3623-7297; Fax: +61-7-3623-7262

Received: 1 January 2014; in revised form: 12 March 2014 / Accepted: 13 March 2014 /

Published: 1 April 2014

\begin{abstract}
A theological exploration of the potential of non-liturgical instrumental music for the transmission of religious Christian faith experience, based on a hermeneutical tool drawn from Jean-Jacques Nattiez as applied to Arvo Pärt's Spiegel im Spiegel. The article explores musical composition, reception, as well as the piece of music in itself, to discover common traits and keys to understanding its "meaning", and relate it to current thought and development in theology; in particular to themes of creativity, theological aesthetics, the Ascension, the artistic vocation and meaning-making in contemporary culture, through music and films.
\end{abstract}

Keywords: music; Nattiez; Pärt; faith and culture; Spiegel im Spiegel; Sequeri, aesthetics; Ascension; presence; semiotics

\section{Introduction: Can Music be "Spiritual”?}

Instead of "starting anywhere", as John Cage might advise, let's start at the end: I invite the reader to listen to a recording of Arvo Pärt's Spiegel im Spiegel [1] (Mirror in the Mirror), before, or during the reading of this article, and to sit for a while with whatever it touches, provokes, or mirrors in you. Each listening to any piece of music, recorded or live, is a new moment of "reception" and therefore of meaning-making [2]. It may lead you to agree or disagree with what is written here, but at the very least it may help you echo with and "understand" it, and in any case, in the context of reflecting on Music and Spirituality, it allows us to enter into our theme through the doorway of experience and to allow that experience to colour, challenge or enrich our theoretical reflections. 
What is it about a piece of music that leads it to be recorded in twelve different versions (cf. [3,4], p. 32) and used in or as the soundtrack of fourteen films, (and counting) [5]? Is it already a "classic", in Gadamarian philosophical or theological terms, or is it too soon to pass judgement? Can we even decipher the reasons behind its "success", and if, in fact, such proliferation of (also) commercial use implies musical quality or rather commodification hinting at the lack thereof [6]? Is the explicitly spiritual and religious inspiration of its composer relevant, making it more "religious" or "Christian" than other music or should we leave that source aside in our reflection? And how do we even begin to answer these questions?

Alongside the general popularity and growing interest in the person and music of Arvo Pärt, there is an increasing volume of scholarly interest and research being published (of particular interest are [7], and the already cited [4]. In relation to the chosen piece of music, Spiegel im Spiegel, and its use in film, an excellent recent study is [8] as it brings together approaches from musicological and film studies). This last study covers a vast range of topics, from biography, through musical theory and musicology to themes of meaning and spirituality. I draw from these sources with the specific aim of identifying and bridging with theological principles and notions which can help orientate and better guide us through the ongoing encounter of Spirituality (in my case, Christian) and the Arts. I am neither a musicologist nor a semiotician, but I am convinced of their importance in a theological understanding of music [9], and hence of the need to collaborate with those who are experts in these fields new to us, challenging as this may be. Music is a powerful symbolic form which I believe can and does enrich human living and mediate the Christian faith experience, perhaps not as an explicit, "complete and computed" proclamation of the kerygma, but as part, or carrier, or even at times as a form of "development" of the same [10]. However, in order to grasp how, we need to take it "on its own terms", rather than trying to "make it fit" into verbal or linguistic paradigms, and open to learning methods of approaching music that can help us do so, and perhaps to recognise the positions or presuppositions underlying our opinions on music and the variety of ways in which a piece of music can be approached.

Why is this important? What are the concerns that underlie this article on music's capacity to reveal God's presence, as exemplified by a hermeneutical exploration of Spiegel im Spiegel? Firstly, the basic and essential one of the Church's relationship with and need to understand culture, as an ongoing "first step" in the dialogue between both; one of theology's tasks is to constantly take that step. Secondly, the conviction that God is present in culture, and that much of our work is to learn to discover that Triune presence, in the many concrete ways that open us to it. And thirdly that music is one of these ways, and this particular piece of music can help us access and understand that. Why is a hermeneutical approach important? Because many of the challenges facing theology and spirituality in our world now are about understanding and interpretation, which in the words of Lawrence Kramer, finds itself "caught between the extremes of resurgent dogmatism and overambitious empiricism" ([11], p. 3). Hermeneutics is a mediator between these two, so although understanding music in itself is already something, it has more to offer, and will enrich in turn our very comprehension of interpretation and meaning:

Nothing is more meaningful than music...not in spite of our clumsiness at saying what it means to us...but because that clumsiness takes us to the very heart of what meaning is... If anything can vindicate meaning, music can, and if it can't, nothing can ([11], p. 7). 
So, the underlying thesis that these pages seek to unfold is the following: music can "mirror" the presence of God, but/and a careful hermeneutical approach to how that happens can help both spirituality, music and theology grow and expand our understanding of revelation and our access to it.

\section{Tripartition Theory as Applied to Spiegel im Spiegel}

For that reason, this reflection will be framed by a hermeneutical tool found in the work of musicologist Jean-Jacques Nattiez [12]. His thought is a tremendous resource for spirituality and theology for the understanding of musical meaning, because not only is he aware of the threefold dimension of any act of human expression common to hermeneutics ("author", "text" and "reader") as applied to music: "composer", "piece of music" and "audience", but in recognition of the complexity of musical performance and meaning, he includes the on-going making of meaning that happens in every arrangement and performance, and organises the variety of ways in which one can receive or "comprehend" music accordingly (cf. [13], pp. 3-53). His approach, known as the Tripartition Theory, or Method, draws from the work of Jean Molino and applies it to musical analysis, developing six possible approaches to understanding music that unfold when the three hermeneutical standpoints of literary criticism mentioned above are applied to musical analysis. He uses the names "poietic processes" for the compositional and creative elements in music (in recognition that this includes composer/s and performers), "trace" for the piece of music itself [14] and "esthesics" [15] for the process of reception. These six approaches depend on whether one:

1. analyses solely the piece of music in itself, or "trace" [Immanent Analysis];

2. moves from an analysis of the piece of music towards an understanding of the compositional process/processes [Inductive Poietics];

3. moves from what is known of the poietic processes of the composer or performer to understand the meaning in a piece of music [Deductive or External Poietics];

4. moves from an analysis of the music to how it could (or should) be heard [Inductive Esthesics];

5. focuses on how it is received or perceived by those who listen to it [External Esthesics];

6. combines all the above, which is, of course, the most complete form of interpretation (cf. [16], pp. 140-42])!

The beauty of this method, above and beyond its obvious thoroughness, is that it calls us to an awareness of the presuppositions that colour our opinions and appreciation of music, and in the quest for a fuller, more truthful understanding of meaning [17], does not allow us to remain complacently or at least unquestioningly in any given position. Why is such diversity or complexity necessary or helpful, when a more simple threefold approach suffices in literary criticism? Because the non-discursive and non-referential nature of music means its meaning is not linguistic, and therefore less easily discernible. Although all communication, including the verbal or discursive can be ambivalent or ambiguous, music is both freer and more embodied, and therefore although we "feel" it more viscerally (I contend), precisely what we are feeling or experiencing, and why, is harder to pinpoint - therein its strength and its challenge. And the need to be careful and thorough about where we draw our conclusions from when we pronounce a word on the spiritual or theological meaning of music. 
My choice of Nattiez as a framework is due to the comprehensive nature of his work and its provision of a hermeneutical "tool" - a method - as opposed to the equally necessary defence of hermeneutics. There are other musicologists who take important hermeneutical approaches to musical analysis and criticism: Rose Rosengard Subotnik's work in challenging structural listening as the sole mode of accessing musical meaning was ground breaking (cf. [18], pp. 148-76) and animates even now reflection on a variety of approaches to musical scholarship [19]. Susan McClary's work is paradigmatic in expanding a hermeneutic approach to music and introducing feministic perspectives to musicology [20]. And the aforementioned book by Lawrence Kramer offers the best defence of hermeneutics, including but not limited to, musical hermeneutics that I have found ([11], pp. 1-19). However, hermeneutics as a way of proceeding is widely accepted in theology - what is new is the knowledge of how to approach music in that way, for which I believe Nattiez's tripartitional method is exceptionally suited. Despite explicit recognition of the need for interdisciplinary collaboration and its potential to enrich theology, too often theologians have little time or capacity to actually appreciate and integrate musicological perspectives. I would hope that a concentrated focus on this particular approach bridging hermeneutics with musicological studies, applied to a particular piece of music, could prove to be an accessible and beneficial entrance point.

Within this framework, without aiming to be comprehensive, the article will explore aspects of Arvo Pärt's Spiegel im Spiegel ("Mirror in the Mirror") as the particular focus of exploration. The reason behind the choice of music, apart from the obvious one of it being a personal favourite, lies in all three hermeneutical viewpoints: the music is interesting in both style and execution, the composer is explicitly religious in his inspiration and states (without imposing) it, and its reception, omnipresent outside the liturgical and even religious realms. It is also one of those that has attracted more scholarly analysis $[21,22]$. At each point I will bring the music into dialogue with authors or theological notions that can help its understanding.

In order to understand this approach in relation to Spiegel im Spiegel, we need to distinguish:

- The Trace: Leaving aside the composer and people's opinion of his intentionality, we simply look at analyses of Spiegel im Spiegel itself (immanent analysis). Where conclusions are drawn from an analysis about the process of composition and meaning of the composer, we are dealing with the second approach (Inductive Poietics); whereas when the expectation is that this analysis orientate, or even dictate what people could or should hear, it is the fourth (inductive esthesics);

- The Composer: What did the composer intend with and in this music? What does Arvo Pärt think it "means"? Or/and what do those who know him say about his intended meaning? Does what Spiegel im Spiegel provokes in us have something to do with who he is, or how he composes? (deductive or external poietics) [23];

- Reception: We can look at how the music has been or is being received, including both critical reviews and the opinions of "fans" who are musically "untrained" (external esthesics). The importance of its use in films, for example, and how it is received therein, would fit here, and I will, in fact, focus on its use in film. We will tackle the difficulties and benefits of this decision at that point. 
The focus guiding our explorations is that marked by the title: whether and in what way this music can "mirror", or evoke for us the Presence of the divine - or conversely, facilitate our being present to God, and this outside or beyond the realm of the liturgy. Is something of the God revealed in and through Christ accessible in the music, as it is written? Does the spirituality of the composer filter through to those listening, whether or not they share the same beliefs? How does the way in which this music has been received in contemporary culture speak to these questions, and if so, can we draw conclusions about music in general? Although attempting to be as open and critical as possible, my own intuition is twofold: unless we wish to dissect and divide human living, our interiority has to somehow be expressed and accessible in all we do and create, and music is an exceptionally powerful symbolic form; and that God is "more omnipresent" (an oxymoron, I know) than we are aware of, and at work long before ever being identified or named. The fact that this piece music is instrumental and therefore devoid of explicit conceptual meaning (beyond the title), as well as the fact that its reception has been largely extra-liturgical, is an aid in exploring this hypothesis.

As will be clear, the choice of a hermeneutical approach recognises and seeks to honour the contextual and multifaceted nature of our experience of music and our apprehension of meaning in life, all of which, however, must not impede our seeking it. It also has something to say, or mirrors the complexity of Christian living itself, and therein lies the one of the riches of theology's engagement with musical meaning. In relation to any given piece of music, one can be composer, performer, or listener, or all three at the same time - the experience is different, even when the same music is played. As well as this, it is an experience that is "acted out", "performed". Kramer speaks of meaning as "performed" rather than discovered ([11], p. 12). Christian faith is more than the range of doctrines many denominations profess each Sunday in the creed, because any one of these essential truths of our faith can be experienced in a number of ways - from different perspectives. Trinitarian faith allows us to experience life as welcomed by the presence of a God that is family, or as instrumental in welcoming others to that presence; faith can enable us to experience ourselves as children or as sharing in a parenthood that is human-divine. Faith is embodied and enacted - the words we pronounce can come alive in and through us as we perform them. Understanding the multi-faceted nature of music can help us to somehow grasp that complexity, or as we shall see, even experience it.

\subsection{Spiegel im Spiegel: The Music}

In order to base our reflections on the piece itself and the musical genre it belongs to, we will start with "the trace". It is probably worthwhile mentioning that as a new form of music, there is much debate, not only around its meaning, exemplified in those exalting its "transcendent" or "sacred" tones and those who consider it "simple" or "flat" ( $c f$. [22], p. 65), but even among those extoling its worth, the issue of how to analyse it remains a challenge [24,25].

Spiegel im Spiegel, depending on the speed it is played at, is a nine or ten minute long piece of chamber music for violin and piano (although it can be played an octave lower by a cello) and has been adapted for other instruments such as clarinet, alto-flute, horn and double bass. It is instrumental, and therefore the only textual reference it has is the title: Mirror in the Mirror. It is the last work that Pärt completed before leaving Estonia, considered one of the earlier pieces of his renowned tintinnabuli style [26]. Much has been written about this style of composition, created by Pärt in the mid seventies 
and for which he has become renowned, so that a comprehensive description of what it implies and the positions surrounding it exceed the limits of this article, but by way of introduction, it is a deceptively simple style consisting of a combination of what Paul Hillier calls "the horizontal and vertical manifestations of pitch" ([7], p. 90); that is to say, melody and the type of "harmony", or better said, sound that emerges by the interaction of both. Two voices blend together: triadic arpeggios, repeatedly unfolding the major triad (Do-Mi-Sol), and a melodic line, which moves diatonically (along the tonal scale) in stepwise motion ( $c f$. [7], p. 93).

The style has been coined "holy minimalism" by many, in reference to both its links with minimalist music as a musical style and the religious inspiration of its composer. Above and beyond the connotations of these names, "minimal" seems a good description of the music, which is carefully built, and moves slowly, silence and space being equally important to its development. Kaire Maimets-Volt integrates this dimension of silence, making it perhaps the most complete linguistic description for our purposes:

In short tintinnabuli is a peculiar kind of stringent diatonic polyphony, created from tonal material outside the paradigm of functional harmony, and built on strictly defined principles around three essential elements: (1) the triad which rotates; (2) the linear melodic line which moves in stepwise fashion; and (3) silence which is used as musically creative element ([8], p. 10).

So the overriding quality of this music is what one could call its "harmony-made-melody". Spiegel im Spiegel is a melodic-harmonic whole - "the harmonic framework tilted sideways to form a musical line" ([7], p. 90), an open melody consisting, precisely in the unfolding of its harmony. "In principle these two parts join to form an inseparable whole - a twofold single entity" ([8], p. 58). This is reflected by the nomenclature theorists use to analyse the music: "M-voice" (for melody) and "T-Voice" (for triad) as opposed to melody and harmony.

It seems to me that it is precisely this harmonic space that opens in tintinnabuli music that makes it so apt for spiritual interpretation, and specifically one involving open space and presence. The relationship of the arts to time and space is an ongoing theme in theology. Jeremey Begbie's development of music's relationship to time is well-known [27]. Before him, Bernard Lonergan related different art forms to dimensions of time and space: painting, sculpture and architecture to space, and music to time, respectively [28]. Music is temporal - it implies time to play, listen and experience it, but perhaps the strongest aspect of human life that music affects and makes us aware of is our bodies and therefore how we experience the space we're in, the way we exist and move in space. Now it seems to me that there are types of music that accentuate more our corporality, invading our sensorial space with rhythms or harmonies that awaken us, literally, by stimulating and moving us physically, (one of the reasons that jogging and iPod culture work together so well?). And that there are other types of music that somehow do the opposite: they slow us down; they stretch our awareness of ourselves, those around us and the world we inhabit, precisely because of their "emptiness". We wonder what's coming next, and wait for it; we become more aware of the other notes and their relationship to each other, precisely because there are so few, rather like being in a room with one other person as opposed to a crowd: attention is heightened. Musical semiotics identify relation and integration (in comparison to definition) as one of the characteristics that differentiate music from 
verbal communication: music works with relationships and tensions "between" notes - one always understood in relation and curving towards the other, be it in melody or harmony. A genre or style of music whose main focus is precisely in a "harmonic melody" could be expected to facilitate or engender a heightened awareness of our presence in relation to the world and each other ([9], pp. 120-27; [29]). Could we not suggest a musical parallel to negative theology's conviction that no matter how much we say about the divine, there is always more we will never be able to express, so let us start in that more humble and truthful humble space...which God inhabits more easily than our words; or at least more silently. After all, the empty tomb is a "sign" of the resurrection of the body, as we shall see later.

Let us look at Spiegel im Spiegel itself. Tintinnabuli music has had more than one manifestation or stage of development. Hillier identifies three: the first works of the later 1970s and early 1980s, those of the mid-1980s to early 1990s, and finally the mid-1990s to the present time. However, the compositions always circle "around the same basic set of images and never entirely quitting the basic tenets of the tintinnabuli aesthetic established in the 1970s" [30]. In this article we focus on a piece from the earlier period, composed in the 1970s. Spiegel im Spiegel itself is written in F major, and the tonic note or root $(\mathrm{F})$ is maintained in arpeggios by the piano, around which the violin constructs a melody circling the third (A) as its centre, to which it always returns. Cizmic notes that although "Pärt places his composition squarely within the tonal world" he refuses "the hierarchical and teleological conventions of functional tonality" ([22], p. 69). That is the case here: in the melody, although F is the base note of tonal music, and therefore the tonic note, Pärt gives more emphasis to another note, taking the third as the centre-point of the melody, to which he constantly returns at the end of each musical "phrase", creating what I can only describe as an open, or stretched harmonic space, since it is neither dissonant, nor unfinished, but "stretched", and that in being so, it seems to "leave space" in which we can feel or experience something.

For a full theoretical analysis of the music, I refer to the excellent and thorough presentations available in that field to be found in both Cizmic ([22], pp. 68-71), her exploration of its use alongside pieces by Shostakovich and Góreck [31], and Maimets-Volt ([8], pp. 64-68), showing several convergences despite the diversity of their analytical aims. Cizmic contains insightful elements of both inductive poietics and inductive esthesics. Based on an immanent analysis of the score, she questions two anthropological and epistemological presuppositions that condition, albeit often implicitly, positive and negative evaluations of his music (and music in general): a neoplatonic Augustinian model and an autonomous modernist one. She recognizes in the music an opening of time and space:

The pacing - the unwaveringly slow speed and rhythmic tempo-provides time and space for a listener to focus in on a single note and experience it, its overtones, and any sort of nuance (such as vibrato or lack thereof) that the performer chooses to enact, before hearing it slide on to the next note ([22], p. 105; [32]).

This opening can create "a static state of being" underlining the experience of time and endurance ([31], pp. 31-32; [33]).

Maimets-Volt offers two different analyses: the first based on the field of musicological cognition, suggesting meaning within Spiegel im Spiegel as a piece of concert music (inductive esthesics). The second is based on its reception in films and using analysis based of film study and cultural semiotics, 
which we will look at in the section on reception. In the former, she focuses on the overall perceived "sound" of tintinnabuli music, including the score but not limited to it, which she defines as the "complex acoustic phenomenon depending on compositional and performance features, yet irrespective of a particular instrumental/vocal timbre" that makes tintinnabuli music "immediately recognizable for listeners" ([8], p. 56). In the words of Hillier: "a sound which appears hauntingly simple, though it stirs complex emotions, and is immediately recognizable" [34]. She explores its emotional meaning, recognizing that, although the relation between music and emotion is not the only one of importance, it is one of the overriding aspects of human living that has been consistently explored in musicology. Some of the musical attributes of Spiegel im Spiegel that she identifies are the following:

- major mode, clear modal centre (although firmly tonal, not necessarily grounded in the tonic);

- $\quad$ steady pulse, regular meter;

- perceived speed: slow-yet the piece is metrically/temporally layered, featuring smooth flowing motion;

- $\quad$ prevailing register space: middle and a melodic range;

- $\quad$ small pitch level variation within one voice;

- homogeneous, viscous and resonant sonic texture, constant sound (no silences filled with overtones);

- $\quad$ smooth (legato) articulation ([8], pp. 64-66).

Following the analytical tools of Gabrielsson and Lindström ([35], pp. 235-42), she associates these musical features with the following discrete emotions, albeit in terms of possibility (what it may evoke), and not necessity (See Table 1), and contrasts this with what is said or commented on in its reception, within which she notes that some reactions are more "expected" than others. She also points out the poetic nature of its description. In the following chart, I take her findings on both (analytical tools and features gathered from commentaries on its reception), and organise them according to Nattiez's tripartitional method.

Table 1. Inductive Esthesics and Free Commentary.

\begin{tabular}{|c|c|c|}
\hline \multicolumn{2}{|c|}{ Inductive Esthesics } & Free Commentary [actual] \\
\hline Immanent Analysis & Esthesics [expected] & \multirow{5}{*}{$\begin{array}{l}\text { Floating; } \\
\text { Luminous and slow; exquisite; beautiful; } \\
\text { a sad and simple idyll; longbreathed; } \\
\text { dreamy aura; } \\
\text { "an extension in time and space" } \\
\text { concentric/centripetal movement } \\
\text { transitional/ascending movement } \\
\text { sweeping, chorale-like arches spreads } \\
\text { itself out more and more. It thus gives } \\
\text { rise to a new architectonic configuration } \\
\text { like a meditation chapel, } \\
\text { stimulates reflection, prayer or the desire } \\
\text { for redemption. }\end{array}$} \\
\hline Major tone & $\begin{array}{l}\text { happiness/joy, expressions of } \\
\text { gracefulness, sereneness, and } \\
\text { solemnity. }\end{array}$ & \\
\hline Narrow melodic pitch range & $\begin{array}{l}\text { Expressions of sadness, dignity, } \\
\text { (pitch) range sentimentality, } \\
\text { tranquility, delicateness, and } \\
\text { triumphantness; stepwise motion } \\
\text { may suggest dullness }\end{array}$ & \\
\hline Small pitch variation & disgust, anger, fear, or boredom & \\
\hline $\begin{array}{l}\text { Round envelope (slow tone } \\
\text { attack and decay) }\end{array}$ & $\begin{array}{l}\text { tenderness, sadness, fear, } \\
\text { disgust, boredom, and potency. }\end{array}$ & \\
\hline
\end{tabular}


I have some reservations about even such carefully suggested correlations between musical attributes and emotions, due to the complexity of human emotion and the contextual nature of our making of meaning in culture. However, that emotion and meaning are correlated is undeniable, and her attempt to integrate both musical analysis, anticipated reception/esthesics and free commentary, in the awareness that she is speaking mainly to western cultural sensibility, is thorough, to say the least [36].

\subsection{Reception: Spiegel im Spiegel in the Public Domain}

An acute attention to the performative and contextual aspects of Pärt's music supplies a window on the spectrum of values that early tintinnabuli pieces offer listeners ([22], p. 76).

We move to the perspective of external esthesics: what does the reception of Pärt's music say about the music itself? Before we do so, a word on the importance of reception and where we look to in order to perceive it. There is a basic theological truth that affirms that the People of God have been gifted with an indefectible guarantee of divine presence through the Spirit poured out into our hearts, which the Church has long identified and honoured as the sensus fidelium: an inner sense, or taste for the things of God and their right understanding. With due attention to processes of discernment and calling on the diversity of roles in all things Christian and ecclesial, this basic Christian principle calls us to listen to the Spirit, wherever she may blow [37]. As a consequence, without excluding the voices of those we deem experts, we need also to listen to the ground-swell, of popular opinion and fandom, even our own [38]! So when we look at the reception of any given piece of music, we look to the experts and to the general public. In relation to the music of Arvo Pärt, this is already being done [39]. As our own window in this article I have decided to look at Spiegel im Spiegel's use in film, and in particular Mike Nichols 2001 Wit [40], based on the 1998 Pulitzer Prize winning play of the same title by Margaret Edson, albeit drawing some small references from Tom Tykfer's 2002 Heaven [41].

I am aware that this brings another complex, multi-media artistic form into the arena, with the analytical demands that this implies and which the space of this article must postpone for further development, yet the fact remains that for many people, it is, in reality, through film that they first meet Arvo Pärt's music, and even more importantly, due to the non-referential and non-representational nature of music's symbolic form, it is, in a sense, another way of accessing the meaning people make of it, both by the director and the public [42]. As such it has something to offer us. How this music is thematically placed and paired is not indifferent to what Spiegel im Spiegel mirrors for contemporary western culture. Maimets-Volts, drawing on Dean Duncan's thesis on the benefits of looking at "serious" music through the lens of film [43], specifically presents the use of Arvo Part's music in film as a helpful way to access what she calls "complex meaning categories" such as "sacred" or "transcendent", or what Philip Tagg calls the "paramusical [44] field of connotation" meaning, which canonical musicological discourse tends to avoid, but which serious attention to its reception can help us access ([8], pp. 16-17). It is a form of external esthesics and the particularity and clarity to be found in this approach to musical meaning may be an aid to contemporary theological reflection in avoiding the generalisations that often plague commentary on music. It also obeys the incarnational principle of our access to the universal being through the particular, recognised also in studies on interpretation as the capacity of the concrete to give us access to the universal ([11], p. 18). 
So what can we discover in these films? Once again, I would invite the reader to preface his reading of this section with some experiential entry points: 4 scenes in Wit have Spiegel im Spiegel as part of their "soundscape" [45], as well as playing us out during the final credits. It is not necessary to repeat the attentive and thorough analysis already presented elsewhere (cf. [8], pp. 146-58), but suffice it to say the film narrates the journey of 48 year-old professor Vivian Bearing (played by Emma Thompson) through terminal cancer to death. Dr. Bearing is an intense and demanding John Donne scholar, and the first appearance of this music in the film comes at minute (0:06:27), while listening to the equally rigorous professor E. M. Ashford (played by Eileen Atkins)'s explanation of John's Donne's "Death be not Proud". The point of the explanation is the importance of right punctuation:

Gardner's edition of the Holy Sonnets returns to the Westmoreland manuscript source of 1610. Not for sentimental reasons, I assure you, but because Helen Gardner is a scholar: "and death shall be no more, (comma) death thou shalt die. Nothing but a breath, a comma separates death from life everlasting. Very simple really. With the original punctuation restored, death is no longer something to act out on a stage, with exclamation points. Death is a comma, a pause. This way, the uncompromising way, one learns something from the poem, life death, soul, past present, not insuperable barriers, not semi colons, just a comma....

The second time it appears is as part of a soliloquy of Vivian (who often "breaks the fourth wall to address the 'audience"') on the passing of time (0:28:11):

Do not forget that you are seeing the most interesting aspects of my tenure as an in-patient receiving experimental chemotherapy of advanced metastatic ovarian cancer. But as I am a scholar I feel obliged to document what it is like here most of the time between the dramatic climaxes. In truth, it is like this: "You cannot imagine how time can be so still...It hangs. It weighs. And yet there is so little of it. It goes so slowly. And yet it is so scarce. If I were writing this scene it would last a full 15 minutes. I would lie here and you would sit there... Not to worry: Brevity is the soul of wit.

The third time the music appears at $(1: 17: 30)$, considered by some to be the centre of the film, it accompanies a movingly human and compassionate re-encounter between the suffering professor Ashford and Vivian, just before she dies, in which Ashford sits beside her on the bed and reads, not Donne's metaphysical poetry, but rather a child's story: The Runaway Bunny (by Margaret Wise Brown and Clement Hurd), a little "allegory of the soul" and leaves her, ("Time to go"), now sleeping peacefully, with a kiss and the words of Shakespeare: "And flights of angels sing thee to thy rest."

Finally, the voice of Vivian reciting John Donne's "Death Be Not Proud" is the over-voice in the final scene of her, dead, in the hospital bed, and continues through the credits.

So the underlying themes are those of life, suffering, death, time, eternity, truth, humanity, compassion...to name the most obvious. And the film is masterfully done [46]. The music accompanies tragic themes without being melodramatic or sentimental ([22], p. 74; [47]). It seems to open a space and time in which to experience "something" which in this case is eloquently verbalised through the poetry of Donne. In saying this I do not wish to present the soundscape of these scenes as the ultimate key to understanding Spiegel im Spiegel's meaning, nor to claim that the sense this film gives it (and it 
gives the film) is the "right" one, but rather to illustrate the potential of this music to accompany and highlight these kinds of themes. It is not an isolated instance. Without going into such detail, Tom Tykfer's Heaven deals with themes of redemption, forgiveness, justice and even, albeit implicitly, ascension and heaven, with a similar use of Spiegel im Spiegel and another early tintinnabuli piece: Für Alina. In Heaven, Mirror in the Mirror appears non-diagetically [48] as the backdrop to our main character's "confession" and forgiveness. The common denominator seems to be the music's capacity, not so much to reflect the emotions of the characters, or provoke emotion in the audience, but rather to "slow down time" and open a space in which we can feel or experience at a deeper and freer level. It exemplifies Kutter Callaway's description of the shift in contemporary film music from "predetermined emotionality to an invitation to feel" ([49], pp. 18-26).

Maimets-Volt talks of tintinnabuli music as used in film as opening a "sphere of beyond", or even "third presence" ([8], pp. 132-35; 170-73). By this she means a "gaze from a transcendental sphere" ([8], p. 172), a timeless sphere beyond space and time ( $c f .[8]$, p. 135). She attributes this to the way in which the music is situated in the film - thematic, rather than compositional-technical and takes it quite far, understanding this space as one of "eternal values", albeit not necessarily understood in an explicitly religious sense. Pärt's compositions:

create and belong to a sphere of eternal spiritual values or ideals ... [such as] humanity/humaneness, empathy, mercy, compassion, goodness/ kindness [...] categories of the sacred, spiritual, and transcendental present in this sphere-though not necessarily in an ecclesiastical sense ([8], p. 172).

Whether or not one agrees that this capacity is inherent to the music, or rather that its combination with depth of thought in narrative, gifted acting, directing, and producing, it seems to me that something of its potential is witnessed to in this, and other films, both from the way they are integrated in the films' soundscapes and its reception by the general public: it opens us to the sense of a presence which is neither that of the actors and their understanding of the narrative, nor the viewers. Without stating that the music explicitly mediates divine presence, or even values we attribute to God, it creates space to negotiate between the human realm and that which is "Other", the awareness of questions that although not easily answered, are not impossible either; "inhabited" space, (if only by those few notes/bells) that is not desolate, and yet still space.

"Third" is an interesting word with theological resonances of perfection and a Trinitarian. Cultural studies and education refer to "third space" as an "in-between" space on the boundary to navigate between different forms of understanding [50], or between clearly defined cultures in hybrid situations; a place that bridges, converses and transforms [51]. From a theological perspective, Trinitarian theology has long appreciated the need for a "Third" to open up relationships, and there are many liminal and boundary situations in Christian faith: God and humanity; Christian faith, other faiths, and the ever increasing "nones"; not to mention the muddled up world we carry inside, where doubt and faith cohabit peacefully or otherwise. In the fast-paced world we live in, where finding the "space" to "reflect, rest and reset" [52] in-between activities is challenging, music such as Spiegel im Spiegel is proving useful for that "third presence". The question of what could be "happening" theologically in that open space is one I will come back to in the final moment of this article. First, let us turn to the composer. 


\section{3. "Behind the Mirror": Poietic and Performance Processes in Spiegel im Spiegel}

Much has been made of Pärt's explicit religious background and inspiration in relation to Orthodox Christianity, but also of his unwillingness to tie the meaning or truth of any given piece to his own understanding of it. However, the question remains: is the religious connotation given to his music due to the person of the composer, whose inspiration is common knowledge? Or is it something inherent in the music itself? The bell-like sound and repetition, for example, can evoke associations of a religious nature. In an article continuing her reflection on Pärt's tintinnabuli music, Maimets-Volt, while presenting an analysis of the effect of the sound of his music in its listeners, still explicitly suggests that there is remarkable convergence between what the composer intended and its listeners perceive or experience ([53], pp. 56-57).

In relation to the piece of music in question, I have found no specific reference by Pärt to his inspiration behind or meaning of Spiegel im Spiegel, apart from some rather clear instructions on its performance:

According to British violinist Daniel Hope, Pärt gave him the following instructions for performing Spiegel im Spiegel: "The sound should be cold, not warm, otherwise it could drift into sentimentality. Please do not use vibrato... the piece needs a different approach...it is a kind of perpetuum mobile for piano... the tempo will depend upon your bow speed. Otherwise I have very little to say" (Quoted in [8], p. 66; [54]).

It would appear that at least this invitation to restraint in regard to sentiment as transmitted by a specific way of playing (vibrato) has carried over into its reception. About the use of this piece of music in film, or indeed his film music in general, Pärt has spoken little and indeed shown little interest ([8], p. 10). Despite, or even because of the lack of commentary on its meaning, some light can and should be drawn from his approach to and understanding of the style within which it is situated: his tintinnabuli work. By way of background, although this is the work he is currently famous for, his early career lead him from neoclassical, through serialism and collage techniques, until in the 70's after what has been called his "silence" in musical composition (in the sense of producing new, finished pieces), he emerged with this approach to composition. Immediate influences on the tintinnabuli style are his conversion to the Russian Orthodox Church, and in particular its mystical/contemplative (hesychastic) tradition and the art of icon painting. In musical terms, the specific influence was the Russian tradition of bell ringing at Orthodox churches, (from whence the name-tintinnabuli) [55]. Other known influences are early music, including Gregorian chant, early polyphony, medieval and renaissance music.

So what does this music "mean" to Pärt? Why this time of withdrawal and new form of creative musical expression? In seeking the answers, care must be taken to separate Pärt's own words and position on the meaning of his music from the opinions of those who write about him, and albeit recognizing that much of what is written does reflect his own position, constraints of space lead me to limit myself here to what Pärt himself has said [56-58].

Tonal Music and Composition born from within: 
The intention behind this withdrawal is described by the composer as the quest for what would be the roots of tonal music and his own integrated way of composing, born from within rather than in the imitation of other styles ([7], p. 91; [30]).

I build with the most primitive materials - with the triad, with one specific tonality" ([58], p. 120).

The importance of silence for Pärt is paramount:

Before one says something, perhaps it is better to say nothing. My music has emerged only after I have been silent for quite some time, literally silent. For me, "silent" means the "nothing" from which God created the world. Ideally, a silent pause is something sacred...

He relates this silence to love:

If someone approaches silence with love, then this might give birth to music. A composer must often wait a long time for his music. This kind of sublime anticipation is exactly the kind of pause that I value so greatly ([3], p. 35).

He explicitly relates the triad in his music to bells:

"The three notes of a triad are like bells. And that is why I called it tintinnabulation."

Composing is a very conscious a spiritual quest:

Tintinnabulation is an area I sometimes wander into when I am searching for answers-in my life, my music, my work. In my dark hours, I have the certain feeling that everything outside this one thing has no meaning. The complex and many-faceted only confuses me, and I must search for unity [59].

This unity or oneness as a source of comfort:

"This one note, or a silent beat, or a moment of silence, comforts me" ([7], p. 87).

This process, although "hard work", does not aim at complexity, but rather the constant effort to identify, simplify and reduce:

It seems, however, that this unknown territory is sooner reached by way of reduction than by growing complexity. Reduction certainly doesn't mean simplification, but it is the way $\ldots$ to the most intense concentration on the essence of things ([60], p. 2).

"The capability to select is important, and the urge for it. The reduction to a minimum, the ability to reduce fractions - that was the strength of all great composers" ([58], p. 114).

There is discipline and craft to his composing - the aim is to work towards the nucleus of a piece, its core. This can take time, and yet, composing is a necessity to him:

For me it's like breathing in and out. It's my life... [C]an I exist without composing, my soul and my spirit? Music is already my language. My music can be my inner secret, even my confession... Most important for me: that I cannot say in a few thousand sentences what I can say in a few notes (cf. [58], p. 113).

He is very explicit about the religious significance of the style of music he has created: 
"Religion influences everything. Not just music, but everything” ([57], p. 132).

Not only in its inspiration but also its meaning:

Pärt described to me his view that the M-voice (melodic line) always signifies the subjective world, the daily egoistic life of sin and suffering; the T-voice (triad underlying, meanwhile, is the objective realm of forgiveness. The M-voice may appear to wander, but is always held firmly by the T-voice." This can be likened to the eternal dualism of body and spirit, earth and heaven; but the two voices are in reality one voice, a twofold singly entity ([7], p. 96).

Centrality of the words and text are central to his composing:

"The words are very important to me, they define the music...the construction of the music is based on the construction of the text" ([58], p. 123).

In relation to the theological themes that inspire his thought and linked with what we have come across in our exploration: On time and eternity:

"Time and timelessness are connected. This instant and eternity are struggling within us. And this is the cause of all our contradictions, our obstinacy, our narrowmindedness, our faith and our grief"' ([58], p. 112).

On space and place:

In this depth, we are all so similar that we could recognize ourselves in any other person ... I am very much tempted to see this beautiful and neat Ur-substance, this precious island in the inner seclusion of our soul, as the "place" where, over 2000 years ago, we were told that the Kingdom of God would be-inside us...And so, I keep trying to stay on the path that searches for this passionately longed-for "magic island", where all people (and for me, all sounds) can live together in love" ([61], p. 49).

So if we try and read these words in the light of Nattiez's framework and ask the question: what could or should the listener hear of what the composer "meant" in its composition, in one sense, we can say: nothing; for although Pärt is very clear about his own inspiration and processes, and even about the meaning he gives tintinnabuli, he does not suggest that what he means is what the listener should hear (cf. [58], p. 111). However, we have much information of what he experiences and how he understands his music, and external esthesics invites us to ask how much of what the composer intended can be heard? Perhaps the best way to gather the disperse threads could be in visual form, simply to see the convergences that are emerging.

The convergence and interaction is significant, even accepting that culture conditions how we receive everything, music included. I will not try to tie down further how this interaction "happens; for the moment it is enough to recognise and be aware of the multitude of connections: silence-focus and experience, time and timelessness - extended in time and space, simplification-holy minimalism. For the purpose of this article, what remains is to pull the threads further on how theology could understand this whole dynamic. The table below (Table 2) tried to do just that, guided by Nattiez's methodology: 
Table 2. Spiegel im Spiegel-Poietic, immanent and esthesic approaches [62].

\begin{tabular}{|c|c|c|}
\hline $\begin{array}{c}\text { Arvo Pärt's Poietic Processes in } \\
\text { Tintinnabuli }\end{array}$ & $\begin{array}{l}\text { Immanent Analysis of } \\
\text { Spiegel im Spiegel }\end{array}$ & Reception of Spiegel im Spiegel \\
\hline \multicolumn{3}{|c|}{ Method 6: Bringing together Poietic, Immanent and Esthesic Approaches } \\
\hline Film Music_-little interest; & 12 versions in 14 different films; & $\begin{array}{l}\text { classical masterpieces given over to } \\
\text { soundtrack clichés; }\end{array}$ \\
\hline $\begin{array}{l}\text { Cold sound, not warm, otherwise it } \\
\text { could drift into sentimentality. } \\
\text { Please do not use vibrato...[Spiegel } \\
\text { im Spiegel performance]; }\end{array}$ & $\begin{array}{l}\text { prevailing register space: middle; } \\
\text { small pitch level variation within one } \\
\text { voice; } \\
\text { homogeneous, viscous and resonant } \\
\text { sonic texture, constant sound (no } \\
\text { silences filled with overtones): } \\
\text { smooth (legato) articulation. }\end{array}$ & $\begin{array}{l}\text { Emotional neutraliaty and distantiation; } \\
\text { Luminous and slow; exquisite; } \\
\text { beautiful; } \\
\text { a sad and simple idyll; longbreathed; } \\
\text { dreamy aura; restrained tenderness; } \\
\text { languorous and incantatory; }\end{array}$ \\
\hline $\begin{array}{l}\text { Quest for the roots of tonal music } \\
\text { triad related to bells: } \\
\text { Oneness as comfort; }\end{array}$ & $\begin{array}{l}\text { Tonal but modal } \\
\text { major mode, clear (modal) centre; } \\
\text { Open harmony; combination of the } \\
\text { horizontal and vertical manifestations } \\
\text { of pitch; diatonic polyphony; } \\
\text { Harmonic melody-melodic harmony; }\end{array}$ & $\begin{array}{l}\text { Themes of life, death, compassion and } \\
\text { forgiveness, war, suffering, the } \\
\text { Holocaust, terminal illness, terrorism, } \\
\text { and } 9 / 11 \text {; }\end{array}$ \\
\hline $\begin{array}{l}\text { Relationship time and timelessness } \\
\text { the tempo depends on bow speed }\end{array}$ & $\begin{array}{l}\text { Fixed rhythmic ordering within each } \\
\text { phrase/pacing - the unwaveringly slow } \\
\text { speed and rhythmic tempo; } \\
\text { steady pulse, regular meter; } \\
\text { perceived speed: slow-yet } \\
\text { metrically/temporally layered, featuring } \\
\text { smooth flowing motion; }\end{array}$ & $\begin{array}{l}\text { Timeless; } \\
\text { an extension in time and space; } \\
\text { concentric/centripetal movement- } \\
\text { transitional/ascending movement; }\end{array}$ \\
\hline $\begin{array}{l}\text { Importance of discipline and craft; } \\
\text { own integrated way of composing: } \\
\text { conscious spiritual } \\
\text { simplify and reduce; }\end{array}$ & strictly defined principles; & $\begin{array}{l}\text { paths to transcendence; Religiousness- } \\
\text { "holy minimalism"; sweeping, chorale- } \\
\text { like arches new architectonic } \\
\text { configuration; meditation chapel; } \\
\text { stimulates reflection, prayer; }\end{array}$ \\
\hline $\begin{array}{l}\text { Space as God/the Kingdom in the } \\
\text { inner seclusion of our soul; Heaven } \\
\text { and earth-body and spirit; }\end{array}$ & "sphere of beyond", "third presence". & $\begin{array}{l}\text { Floating; } \\
\text { spirals of inner reflections; }\end{array}$ \\
\hline $\begin{array}{l}\text { Otherwise I have very little to say } \\
\text { Silence; Silence related to love; }\end{array}$ & Silence & $\begin{array}{l}\text { Provides time and space for a listener to } \\
\text { focus in on a single note and experience it; }\end{array}$ \\
\hline
\end{tabular}

\section{Echoes in Christian Theology: Gathering Insights}

My guiding words in this section are verbs (albeit "passive" or rather reflective ones): mirroring and echoing. Spiegel im Spiegel mirrors something to us, not least the very potential of music to mediate something to human life. And theology at its best echoes something of the truth of who God is and what it is to believe, not because truth is weak, but because its strength lies also in that it is ever beyond our full comprehension, and knowing that keeps things in perspective: any insight will always be subject to growth and/or correction. So what theological echoes do we hear, having come this far in our reflections? I will frame these concluding thoughts in the threefold structure we have been working with. 


\subsection{The (Third) Presence of Christ in Music}

As will have become clear by now, in the writing of this article the key words that have emerged are space and presence - the power of empty space; the power of music that does not impose or control what we feel, but creates a space that invites us in. As mentioned above, it evokes the memory of that part of Apologetics that used to present the empty tomb as a "proof" of the resurrection. We no longer speak of "proof" in that way, of course, but the empty tomb is still an important part of resurrection theology, as a sign and message about the embodied nature of Jesus' life, and our own. There is something powerful and evocative in the thought that emptiness could be or facilitate the presence of someone - that the lack of one body could mean, or make present, a different, transformed one. It seems to me that this is one way in which music, and specifically Avro Pärt's Spiegel im Spiegel works. It opens a space for us to experience another, "Third" Presence. We already noted music's effect on how we inhabit the world, drawing on Speelman's musical semiotics. Is there a doctrinal, revealed truth that relates to this experience? The one which could underlie some of what we touch there is that of the continuing presence of the Incarnated Body of Christ in our world, which paradoxically is inaugurated by (and could even be understood as a kind of "flip-side of the coin" to) the Ascension. This truth, essential to the life of the early Church but rather peripheral to ours today, is somehow alien or distant to us precisely because of the different way in which we inhabit the universe and "imagine" heaven, where Jesus (presumably) has "gone". And yet for a pre-Copernican world, the risen and ascended body of Christ was still "within our reach", as it is still within ours. Space is not empty, when we can bear to let it breathe the Presence of the One in whom we live, move and have our being (Act 17:28).

The past ten years has seen research into the doctrine of the Ascension and its corresponding doctrine of the mystical body of Christ intensify and deepen [63]. Groundbreaking in this regard is the recent work of a recent approach to theology at King's College, London by Oliver Davies, Paul Janz and Clemens Sedmak, called Transformation Theology [64]. Of particular note is the mutuality they underline between the Ascension and Body of Christ, by which they challenge the implicit or explicit "substitution" of the post-Paschal humanity of Christ by the Spirit, re-situating the same as the "life/breath" of the risen and ascended body of Christ. Hence, current theological exploration of our embodied lives in Christ [65], both personal and as community/ society touch upon this truth, albeit implicitly, however it may be named or described: Transformation Theology, the Body of Christ, the Mystical Body of Christ, Immanent Transcendence or God's inspiriting presence ([49], pp. 139-48), the dispersed body of Christ ([66], pp. 168-69), the fourfold bodily expression that popular music works through (physical, social, symbolic and metaphorical) ([66], pp. 57-72), or the Ascension of our lord to Heaven. I have no evidence (apart from the film's title!) to suggest Tykfer was thinking along these lines, but in the last scene of the Heaven, they "ascend" ever upwards. We cannot hear the music,

"...yet the reason why we, the viewers, cannot hear it, is because in the end we are left behind with an earthbound point of view (confirmed by the last shot of witnessing the ascent of the helicopter), while the protagonists are completing their ascension into heaven" ([8], p.108). 
In any case, the question is left open as to the couple's fate, and it is unlikely that Heaven is "upwards". Interestingly, Pärt himself speaks of a different direction in his own seeking: the space we may well need to find may not be up, but down here and inward, in the "inner seclusion of our soul", and that of each person, that Pärt seeks in and through music. Contemporary understanding of where God inhabits our world (i.e., heaven) is as much about interiority as anywhere else.

\subsection{Reception: The Power of What is not "Said" and The Development of Doctrine}

The fact is that music can and does offer meaning and space for many people. George Steiner calls music the "un-written theology" ([67], p. 218) of many who do not relate to a particular creed or religion. Interestingly and in some sense confirming this fact, Spiegel im Spiegel has no explicit creed attached to it and despite the depth of human meaning to be found in some of the films it has become a part of, they're not explicitly religious or Christian films. They are saturated with meaning, but it is implicit meaning. I left the "soundscape" of Wit differently to how I entered it. In putting name to the values she intuits in tintinnabuli music, Maimets-Volt underlines their human origin, and admits it may seem "paltry", in comparison with the positive revelation of the all-knowing deity Revelation prescribes to" ([8], p. 172). But is that not harsh? Is God who lets his sun shine... (cf. Mt 5:38-48) not more generous than that? Could it be OK to leave space, without words, at times, and know that the divine Spirit is at work anyway? How can a film, or a piece of music, which says nothing about God, transmit God, before or even without, an explication to that effect? Rahner, in a beautiful short piece called "Prayer for Creative Thinkers", in which he simply asks God for more of them, at the service of the Word, states explicitly that

they do not need to be constantly bringing you into everything they say. They must make mention of you by name only when they are filled with the spirit of the purest happiness or the deepest pain. For the rest let them honour you with their silence ([68], p. 131-32).

Why is non-explicit ok? Because God is not a word, and divine presence cannot be "held" in a word, alone: Because we can hold together, quite happily, a deep desire that God be known, and an awareness that God is "in the room", quietly, un-recognized as yet, but moving and effective. That God is not (yet) recognized, or professed does not mean that God is not there, holding us while the Spirit inspirits? Tom Beaudoin's theology of Generation X describes them/us as a generation who are distrustful of institutional religion, consider experience sacred and find spirituality in suffering, and speak of faith and ambiguity" [69]. If that is the case, then we need forums and means to rediscover trust and the bridge to Christ's presence: room to move and sense that God can be found in suffering, useless beauty, interconnectedness, inter-subjective meaning, interpretative space as opposed to commentary, and "hard-won clarity". And one way in which God inhabits is precisely through music.

Not only is this something those alienated for institutionalized religion may need, but also those who have never left. Music not only enriches us towards faith (preambula fidei), but also within it. It can awaken in us those areas that are dormant, or complacent, or simply untouched. Our theology of faith needs to account for the embodied and affective dimensions of life in a more comprehensive way - and perhaps therein lies the strength music has which words don't, "even a few thousand of them". We leave the "soundscape" of Wit differently to how we enter. Our thought is stretched with 
what could be called deeper, thicker and fresher concepts [70], which will enrich not only our experience but also our doctrinal understanding. I think of the notion of "the development of doctrine" also in those terms, less as an accumulation of new concepts and more in the depth with which we experience and therefore understand them. Again, as noted in the above reflection, music comes to our aid in this.

\subsection{A "Third Way" for Contemporary Culture: Creative Thought}

This leads us back to our final viewpoint: the composer and the poietic processes. The theme of the creative process is one that in recent years, from many different (sometimes opposing) angles is emerging in writings on theology and spirituality. For our purposes, there is a useful notion (in poetic continuity with our theme of "thirds") in the thought of Italian theologian and musician, Pierangelo Sequeri which can shed light, in his writing on what he calls a "third way" (terza via), within which "creative thought" is invited to have a leading role. One of the concerns underlying Sequeri's work is the separation and division in the history of Western theology and spirituality between the world of art and that of Religion, and its effect on the spiritual quality of culture [71], from whence he explores the theological potential of music. Interestingly, in an extensive study on the history of western music [72,73], his stance is not that music fills in and substitutes the spiritual in the wake of religion, but rather that music is the art that resists the division most:

"The prophecy of Nietzsche- “Art raises its head where the religions withdraw", has not been very listened to in music” ([73], p. 11).

This, according to Sequeri, is precisely because the history of music in the West has been moved by the very idea that music is able to initiate us into immediate contact with the divine, and the quest to represent or interpret it. However, the basic fact remains - these worlds have separated and that bodes ill for the spiritual quality of both. Sequeri identifies a possible way forward in the role of artists and talent: a "third way" in which creative thought emerges as the "director" of the encounter between the sacred and art. In his words:

Music struggles with the sacred, and the sacred is experienced in art, on the territory of an encounter whose direction is entrusted to creative thought: not only destined for prayer, nor necessarily a stranger to religiosity ([72], p. 508).

The point of interest here is the last phrase - a place common to those who profess a religious faith and those who may not. This is precisely the space much of Arvo Pärt's music, including Spiegel im Spiegel, inhabits. Sequeri calls for:

a new unprejudiced opening to the universe of artistic creation" in which it is not a time for tightening and defining things, but rather for "the liberation of a more evangelical generosity on the part of believers who are convinced and dotted with talent-capable even to draw with them the interest of the world around them ([74], pp. 28-29).

From what we have presented on how Pärt describes what it means to him to compose, I suggest his understanding and response to that creative calling opens precisely the kind of path Sequeri is talking about. Two aspects in particular seem significant: 
- the depth of awareness and explicit clarity about the source of his music-making - the search for Oneness, for peace, for the space within that inhabits every soul-is held together with a serene non-imposition on others of meaning that he inspires his work.

- the amount of hard work, effort and freedom in finding and maintaining his own voice in music, rooted in his quest for God. There is a deep and integrated faithfulness in how he lives out his musical vocation that seems to me to be a space in which God's creative Spirit can touch ours.

Finally, coming back to the initial questions we began with about the potential of music to mirror, or transmit religious experience: from a fully theological perspective and without expecting it to be understood in the same terms for those who do not share that faith and world-view-if the space one inhabits and draws inspiration and music from is an experience of the Divine in whom we live, move and have our being, then surely some of that breath of life and love passes through (as with all love experiences), in the most human-divine way possible, to those who listen? Or even further: revelation tells us that God is present, always; faith is the doorway that opens our eyes to discover and experience that presence. Perhaps the space that is opened by this music somehow draws or gathers people into that place inhabited by God's Spirit, with whom, for a time, we amicably, even if unknowingly, make three tents and dwell for a while.

\section{Acknowledgements}

Much of what is written here was born of the panel organized by Kutter Callaway, Clive Marsh, Vaughan S. Roberts and the joint session of the Music and Religion Group with the Religion, Film, and Visual Culture Group at the 2013 Annual Conference of the American Academy of Religion, called Hearing Images: Film, Music, Meaning-Making, and Lived Religion. Thanks are due to all involved for an exceptional session.

\section{Conflicts of Interest}

The author declares no conflict of interest.

\section{References and Notes}

1. Arvo Pärt. Spiegel im Spiegel. New York: Universal Edition, 1978, UE13360. Although there have been over twelve versions recorded, including a rock and a bluegrass one, I suggest perhaps including in your choice at least one of the original versions for piano and violin or piano and cello.

2. The initial form of this article was a paper for a panel session at the 2013 Annual Conference of the American Academy of Religion in Baltimore, organized as a joint session of the Music and Religion Group with the Religion, Film, and Visual Culture Group, called Hearing Images: Film, Music, Meaning-Making, and Lived Religion. The exceptional nature of this session and its success, among other things, lay in the space created between panellists for live music, at times accompanied by film. 
3. Jeffers Engelhardt. "Perspectives on Arvo Pärt after 1980.” In The Cambridge Companion to Arvo Pärt. Edited by Andrew Shenton. Cambridge, New York: Cambridge University Press, 2012, pp. $29-48$.

4. Andrew Shenton, ed. The Cambridge Companion to Arvo Pärt. Cambridge, New York: Cambridge University Press, 2012.

5. Some of these films are: Mother Night (Keith Gordon, USA, 1996); La chambre des officiers (François Dupeyron, France, 2001); Wit (Mike Nichols, USA, 2001); Gerry (Gus van Sant, USA/Argentina/Jordan, 2002); Heaven (Tom Tykwer, Germany/Italy/USA/France/UK, 2002); Saenghwal $\breve{u}$ i palgyŏn (On the Occasion of Remembering the Turning Gate) (Hong Sang-Soo, South Korea, 2002); Swept Away (Guy Ritchie, UK/Italy, 2002); Ten Minutes Older: The Cello / Segment: Dans le noir du temps (Jean-Luc Godard, UK/Germany/France, 2002); Depuis qu'Otar est parti (Julie Bertucelli, France/Belgium, 2003); Soldados de Salamina (Fernando Trueba, Spain, 2004); Elegy (Isabel Coixet, USA 2008); Gravity (Alfonso Cuarón, USA, 2013); About Time (Richard Curtis, UK, 2013); The East (Zal Batmanglij, UK, 2013).

6. I am gathering not only general Adornian questions around musical consumption, but ones which are raised in relation to Pärt music with frequency, even by the composer himself.

7. Paul Hillier. Arvo Pärt (Oxford Studies of Composers). Oxford, New York: Oxford University Press, 1997.

8. Kaire Maimets-Volt. "Mediating the "Idea of One": Arvo Pärt's Pre-Existing Film Music." Ph.D. Dissertation, Estonian Academy of Music and Theatre, 6 May 2009.

9. For a fuller presentation of my approach to music in theology, cf. Maeve Louise Heaney. Music as Theology: What Says about the Word (Princeton Theological Monograph Series). Eugene, OR: Pickwick Publications, 2012.

10. I am referring to the theological notion of "development of doctrine", made famous by John Henry Newman and integrated into theological discourse ever since, to which I will come back further on.

11. Lawrence Kramer. Interpreting Music. Berkeley: University of California Press, 2011.

12. Born in France in 1945, Nattiez is a musicologist and ethnomusicologist at the Universite de Montreal, Canada.

13. Jean-Jacques Nattiez. "Musical Semiology: Beyond Structuralism, after Postmodernism." In The Battle of Chronos and Orpheus: Essays in Applied Musical Semiology. Oxford, UK: Oxford University Press, 2004.

14. For Nattiez this necessarily implies a musical analysis of the score, understood as descriptive rather than prescriptive, in the sense that performances can and will vary, or "change" the music, but only in the score do we have a "fixed text". I think we need to find an alternative or complementary approach to understanding some contemporary music, due to the nature of certain styles of musical composition and annotation.

15. A neologism taken by Nattiez from Paul Valéry referring to the faculty of perception.

16. Jean-Jacques Nattiez. Music and Discourse: Towards a Semiology of Music. Princeton, NJ: Princeton University Press, 1987.

17. In his words: "[S]ome interpretations are more valid, indeed more true (let us not be afraid of that word!) than others". $C f$. ([13], p. 39). 
18. Although first published in 1988, its fuller version can be found in Rose R. Subotnik. "Toward a Deconstruction of Structural Listening: A Critique of Schoenberg, Adorno and Stravinsky." In Deconstructive Variations: Music and Reason in Western Society. Minneapolis, MN: University of Minneappolis Press, 1996.

19. Andrew Dell'Antonio. Beyond Structural Listening? Postmodern Modes of Hearing. Berkeley: University of California Press, 2004.

20. Susan McClary. Feminine Endings, Music Gender and Sexuality. Minneapolis: Regents of the University of Minnesota, 1991.

21. Spiegel im Spiegel seems to be one of the more frequently mentioned works of Pärt in recent scholarship, appearing in seven of the nine chapters of the recently published Cambridge Companion to Arvo Pärt. It is one of two pieces that the aforementioned book by Maimets-Volt focuses on.

22. Maria Cizmic. "Transcending the Icon: Spirituality and Postmodernism in Arvo Pärt's Tabula Rasa and Spiegel im Spiegel." Twentieth-Century Music 5, no. 1 (2008): 45-78.

23. Geoffrey Turner's presentation of Pärt's work in "Sounds of Transcendence." Cross Currents 45, no. 1, Spring 1995, 62-67, seems to be an example of this kind of approach.

24. The chapter of Thomas Robinson on this theme, for example, explains the adequacy or otherwise of various current methods in relation to this new and distinctive form of composition.

25. Thomas Robinson. "Analysing Pärt." In The Cambridge Companion to Arvo Pärt. Edited by Andrew Shenton. Cambridge, New York: Cambridge University Press, 2012, pp. 76-110.

26. Tintinnabuli, or "tintinnabulation" is taken from the Latin word for "small tinkling bell": tintinnabulum, and only received its name (drawn from one of its inspirations in the sound of bells) after the technique had been created.

27. Jeremy Begbie. Theology, Music and Time. Cambridge: Cambridge University Press, 1997.

28. The context in which he does so is interesting: Topics on Education - the implication being that our apprehension and understanding of art has something to do with what and how we know. For Lonergan - experience is the first step of all knowledge, as presented in Bernard Lonergan. Topics in Education: The Cincinnati Lectures of 1959 on the Philosophy of Education (Collected Works of Bernard Lonergan 10). Edited by Robert M. Doran and Frederick E. Crowe. Toronto: University of Toronto Press, 1993, pp. 208-32.

29. In these pages I explore more fully the significance of the harmonic space created between notes in music in relation to how we inhabit the world, drawing on the musical semiotics of Willem Marie Speelman.

30. Paul Hillier. Tintinnabuli. Booklet notes to CD Arvo Pärt: A Tribute. Paris: Harmonia Mundi, 2005, HMU 907407.

31. Maria Cizmic. "Of Bodies and Narratives: Musical Representations of Pain and Illness in HBO's Wit.” In Sounding Off: Theorizing Disability in Music. Edited by Joseph Straus and Neil Lerner. New York: Routledge, 2006, pp. 23-40.

32. My emphasis.

33. This conclusion is drawn from her analysis of the use of Spiegel im Spiegel in the film Wit, which we will explore further. 
34. The particularity the musical sound of Pärt's tintinnabuli music, which makes it "immediately recognisable" is emphasised by Maimets-Volt's and forms the basis of her analysis.

35. Alf Gabrielsson, and Erik Lindström. "The influence of musical structure on emotional expression." In Music and Emotion: Theory and Research. Edited by Patrick N. Juslin and John A. Sloboda. Oxford, New York: Oxford University Press, 2001.

36. Worth mentioning in this regard, is Susan McClary's work in Conventional Wisdom. Berkeley, CA: University of California Press, 2001, in which she argues that the relationship between music and meaning/emotion is a socially constructed and agreed upon one, and therefore, albeit recognising its limits, can be understood as a well established convention, and analaysed as such.

37. This is a theme of current interest in theology. One resource is the excellent work of Orm Rush in The Eyes of Faith: The Sense of the Faithful and the Church's Reception of Revelation. Washington, D.C.: Catholic University of America Press, 2012.

38. Tom Beaudoin's writing on the theological importance of taking what fans say seriously, in "The Ethics of Characterizing Popular Faith: Scholarship and Fandom." In Witness to Dispossession: The Vocation of a Post-Modern Theologian. Maryknoll, NY: Orbis Books, 2008.

39. The aforementioned Cambridge Companion, fruit of several conferences in recent years on Pärt's work and influence has several chapters on aspects of this theme. Laura Dolp, analyses how from the beginning, ECM's tenacious and comprehensive marketing strategy has sought to promote Pärt's music to an increasingly varied audience, up to and including its use in Fahrenheit 9/11 in "Pärt in the marketplace." In The Cambridge Companion to Arvo Pärt. Edited by Andrew Shenton. Cambridge, New York: Cambridge University Press, 2012, pp. 177-92. Jeffers Engelhardt looks at his influence on other musicians of various genres (including rock and bluegrass!) in [3], pp. 29-48; and Robert Sholl, unfolding themes of mourning, death and enchantment and embodiment, identifies it as a "Soundtrack of our Age" in "Arvo Pärt and Spirituality". In The Cambridge Companion to Arvo Pärt. Edited by Andrew Shenton. Cambridge, New York: Cambridge University Press, 2012, pp. 140-58.

40. Margeret Edson. Wit [film]. Directed by Mike Nichols. New York: Avenue Pictures/HBO, 2001.

41. Krzysztof Kieślowski and Krzysztof Piesiewicz. Heaven [film]. Directed by Tom Tykwer. Santa Monica: Mirage Enterprises, 2002.

42. However, I recognise that a focussed study on the intentionality behind the use of this music by the director and producers of the films, impossible in this space and therefore postponed for further exploration, would enrich and complete this approach.

43. Dean Duncan. Charms that Soothe: Classical Music and the Narrative Film. New York: Fordham University Press, 2003, p. 14.

44. By "paramusical" meaning she is referring to those metaphorical or even metaphysical values, or experiences we seem to access through music, which are not accessible to musical analysis and therefore often avoided by musicologists.

45. I use the word "soundscape" with the meaning offered in Kutter Callaway research which was one of the elements at the root of the aforementioned AAR panel: music and narrative form a whole in which one enriches the other. The cinematic experience is a multi-sensorial one as an intrinsic aspect of its "narrative". 
46. It won the 2001 Humanitas Prize and Peabody Awards, as well as the Berlin International Film Festival Special Prize of the Ecumenical Jury.

47. Cizmic, commenting on the power of Spiegel im Spiegel's use in this film, relates it also to the actual documentation of Arvo Pärt's music in aiding AIDS patients as they faced their death: "In a late twentieth century Western context, Pärt's early tintinnabuli works are heard as expressions of continuity that resonate with representations and experiences of illness".

48. A term referring to music that is not part of the script internal to the narrative.

49. Kutter Callaway. Scoring Transcendence: Contemporary Film Music as Religious Experience. Waco, TX: Baylor University Press, 2013, pp. 18-26.

50. Elizabeth Birr Moje, Kathryn Mcintosh Ciechanowski, Kathrine Kramer, Lindsay Ellis, Rosario Carrillo, and Tehani Collazo. "Working toward third space in content area literature: An examination of everyday funds of knowledge and Discourse." Reading Research Quarterly 39, no. 1 (2004): 38-70.

51. Jennifer Elsden-Clifton, and Kathy Jordan. "The potential of on-line lectures: Reaping the rewards of "Third spaces"." Studies in Learning, Evaluation, Innovation and Development 8, no. 1 (2011): 14-25.

52. Adam Frazer. The Third Space. Sydney: Random House, 2012.

53. Kaire Maimets-Volt. "Arvo Pärt's Tintinnabuli Music in Film.” Music and the Moving Image 6, no. 1 (2013): 55-71.

54. The link between the "space left" for the audience's own experience as noted previously seems to find at least some link to the composer's intentionality here.

55. For a fuller explanation of the roots and significance of the bells to tintinnabuli music, $c f$. Marguerite Bostonia. "Bells as Inspiration for Tintinnabuli." In The Cambridge Companion to Arvo Pärt. Edited by Andrew Shenton. Cambridge, New York: Cambridge University Press, 2012, pp. 128-39.

56. By way of resources for a better understanding of both the person and music of Arvo Pärt, Paul Hilliers aforementioned book draws much from his personal contact and musical involvement with the composer, although it is also coloured with personal opinion and commentary which at times seem to overstep Pärt's own understanding of his music.

57. Jamie McCarthy, and Arvo Pärt. "An Interview with Arvo Pärt." The Musical Times 130, no. 1753 (1989): 130-33.

58. Andrew Shenton. “Arvo Pärt in His Own Words." In The Cambridge Companion to Arvo Pärt. Cambridge, New York: Cambridge University Press, 2012, pp. 111-27.

59. Wolfgang Sandner. Program Notes for Arvo Pärt's Tabula Rasa. Translated by Anne Cattaneo. ECM New Series 1275, 1984, compact disc.

60. Andrew Shenton. "The Essential and Phenomenal Arvo Pärt." In The Cambridge Companion to Arvo Pärt. Cambridge, New York: Cambridge University Press, 2012, pp. 1-9.

61. Leopold Brauneiss. "Musical archetypes: The basic elements of the tintinnabuli style." In The Cambridge Companion to Arvo Pärt. Edited by Andrew Shenton. Cambridge, New York: Cambridge University Press, 2012, pp. 49-75.

62. This figure is a development of one offered by Nattiez himself in ([16], p. 140), and reproduced with permission in ([9], p. 95). 
63. The most recent seems to be a forthcoming book by Anthony J. Kelly. Upwards: Faith, Church, and the Ascension of Christ. Collegeville, MI: Liturgical Press, 2014.

64. I came across their work while seeking a paradigm for the understanding of music, composition and spirituality. This is part of the thesis presented in [9]. Repeating it here is unavoidable if it is true.

65. By way of example, in recent years the theme of our embodiment and the corporality of Christ has been ever more frequent in the American Academy of Religion annual conferences.

66. Clive Marsh, and Vaughan S. Roberts. Personal Jesus: How Popular Music Shapes Our Souls. Grand Rapids, MI: Baker Academic Publishing, 2012.

67. George Steiner. Real Presences. Chicago: University of Chicago Press, 1989.

68. Karl Rahner. "Prayer for Creative Thinkers." In Theological Investigations 8. London: Darton, Longman and Todd, 1971, pp. 130-32.

69. Tom Beaudoin. Virtual Faith: The Irreverent Spiritual Quest of Generation X. San Francisco: Jossey Bass, 1998.

70. Clemens Sedmak. "The Disruptive Power of World hunger." In Transformation Theology. Church in the World. Edited by Oliver Davies, Paul D. Janz and Clemens Sedmak. Edinburgh: T\&T Clark International, 2007, p. 117.

71. Pierangelo Sequeri. "In realtà che cosa possiamo pensare tutti insieme quando diciamo "vita spirituale” e spiritualità?” In Sensibili allo Spirito, Umanesimo Religioso e Ordine degli Affetti. Milano: Glossa, 2001, p. 4. (In Italian). "In reality, what can we all think together when we say "spiritual life" and "spirituality"?" [Translation mine].

72. Pierangelo Sequeri. Musica e Mistica. Percorsi Nella Storia Occidentale delle Pratiche Estetiche e Religiose. Città del Vaticano: Libreria Editrice Vaticana, 2005. (In Italian).

73. Pierangelo Sequeri. La Risonanza del Sublime. L'idea spirituale della musica in Occidente. Roma: Studium, 2008. (In Italian).

74. Pierangelo Sequeri. "Coscienza Cristiana, Ethos della Fede e Canone Pubblico." In A Misura di Vangelo. Edited by Marco Vergottini. Cinisello Balsamo: San Paolo, 2003. (In Italian).

(C) 2014 by the author; licensee MDPI, Basel, Switzerland. This article is an open access article distributed under the terms and conditions of the Creative Commons Attribution license (http://creativecommons.org/licenses/by/3.0/). 